\title{
Validity Triage and Response Time Nurses in Hospitals Emergency Room Sheikh Yusuf Gowa
}

\author{
Thahirah Annisa, Wahdaniah, Risnah, Andi Budiyanto, Saleh Ridwan \\ UIN Alauddin Makassar, Indonesia \\ Corresponding author: tannisa995@gmail.com
}

\begin{abstract}
Background: triage is a complex decision-making process in order to determine which patients are at risk of death, disabilities, poor clinical situation deteriorates, and safe patient for waiting. One of the principles of response time is generally about handling emergency patients who should be treated later than five (5) minutes after arriving at the ER.

Purpose: This study aimed to determine the relationship between the Response Time Validity triage of nurse.

Methods: The study design was observational analytic with cross sectional approach to sampling using Accidental Sampling based on inclusion and exclusion criteria with the number of 18 respondents. Univariate test results obtained from 11 respondents do Triage with appropriate and quick response time doing about 8 respondent. To determine the relationship between the validity of triage and response time by using Spearman rank test test at the significance level of $95 \%$, which gained significant value of $p=0.000$ or less than $0.05(0.000<0.05)$.
\end{abstract}

Results: The results of this study to indicate there is a relationship between the validity Triage and Response Time Hospital emergency room nurse in Sheikh Yusuf Gowa Hospital.

Conclusion: It is expected that this study can be used as a reference for educational institutions and health care institutions.

Keywords: Triage, Validity, Response Time, Emergency Room 


\section{BACKGROUND}

Emergency Room (ER) is a place / unit in a hospital that has a working team with special skills and equipment that provide emergency patient care and is a part of the efforts to combat organized emergency patients (Ministry of Health, 2018). One of the parts from the hospital to provide services is the ER. IGD is a major gateway road emergency admission. IGD is an installation piece hospital that performs actions based triage of patients. Triage is a way of sorting patients based on therapeutic needs and the resources available. Therapy is based on the state ABC (Airway, with cervical spine control, Breathingand Circulation with bleeding control). Triage applies to the sorting of patients both in the field and in the hospital (Musliha, 2010).

The speed and accuracy of help given to patients who come to the ER requires standards in accordance with the competence and capabilities so as to ensure an emergency care with a fast response time and proper handling. According Maatilu (2013) one of the indicators of a successful response to emergency medical patients is an adequate speed to provide relief to people with good emergency on the state of the daily routine or while disaster. The success of the response time or response time is dependent upon the available speed and quality of aid delivery to save lives or prevent defects in the scene, on the way to help the hospital (Mudatsir, 2017). The context of the emergency service, aspects of nursing care at the implementation stage is very important to note, because the execution phase / implementation should refer to the basic doctrines of the emergency services that is time saving is life saving (time is lives), the measure of success is the response time (response time) for 5 minutes and definitive time $\leq 2$ hours (Mahrur, 2015).

The number of visits in the emergency installation requires proper triage system, efisisen and responsible influence on the success of lifesaving and disability prevention (Gravel et. Al, 2009). The role of triage system in the emergency services is determining the priority of patients based on their need for urgent care (Gravel et. Al, 2009). Triage differentiate patients who should receive immediate treatment to patients who can wait in the ER (Hammond, 2012). A large number of patients admitted to the emergency department with a limited number of nurses who lead not all patients get treatment quickly. Joint Commission on Acreditation of Health Organizations (JCAHO) reported in 2002 that more than $50 \%$ of patients who received treatment in the ER experienced death and permanent disability due to delays in treatment (Hammond, 2012).

Differences triage system would lead to differences in the assessment of the gravity of the patient and the prioritization of patients will have an impact on the speed of the gravity of the patients received treatment required (Hammond, 2012). Therefore we need a picture of the validity of triage is performed on patients in the emergency installation. Validity is a look at how the system can measure the correct triage urgency and priority condition in patients as well as the response time perwat in providing services in hospital emergency room Shaykh Yusuf Kab. Gowa

\section{OBJECTIVE}

This study aimed to determine the relationship between the Response Time Validity triage of nurse

\section{METHODS}

This study uses a quantitative research design correlational studies. Research with cross sectional approach seeks to study the relationship between risk factors as a cause for the effects of the cause. The variables studied were validity ER triage nurse in providing 


\section{Journal Of Nursing Practice}

http://thejnp.org

ISSN: 2614-3488 (print); 2614-3496 (online)

Vol.3 No.2. April 2020. Page.153-164

services for patients in the ER as the independent variable and the response time of emergency department nurses as the dependent variable.

Researchers determine the population in this study using the average number of patients from the emergency department in July 2019 in Sheikh Yusuf District Hospital emergency department Gowa.

The sample technique was taken by accidental sampling. Where the consumers who accidentally / incidentally met with the researchers can be used as a sample, when the other people who happened to encounter it suitable according to inkslusi and exclusion criteria. In the determination of the samples, researchers also determined inclusion and exclusion criteria as follows: Inclusion criteria: Nurses who work in the emergency room, nurses who are willing to become respondents and sign an agreement. Exclusion criteria: Nurses who are on leave, the nurse who held the position of the organization (head room). Nurses with holiday service schedule.

The participants were assured that their engagement was voluntary, and that anonymity, privacy, and confidentiality of the data were guaranteed. Furthermore, they were informed about the purpose and the method of the study before signing a written informed consent

\section{RESULTS}

1. characteristics of Respondents

Tabel 1. Frequency Distribution of Respondents by Gender emergency room nurse in hospitals Sheikh Yusuf Gowa $\mathrm{n}=18$ )

\begin{tabular}{ccc}
\hline \multirow{2}{*}{ Gender } & $\mathbf{N}$ & $\boldsymbol{\%}$ \\
\cline { 2 - 3 } & $(\mathbf{F})$ & $\mathbf{( \% )}$ \\
\hline Man & 9 & 50.0 \\
woman & 9 & 50.0 \\
\hline Total & $\mathbf{1 8}$ & $\mathbf{1 0 0 . 0}$
\end{tabular}

(Primary Data 2019)

Frequency distribution of respondents by gender Hospital emergency room nurse Sheikh Yusuf seen from the table above shows that of the 18 respondents were visible, then the sex of the respondents men and women have equal number ie 9 respondents $(50.0 \%)$.

Tabel 2. Frequency Distribution of Respondents by Age Nurses in hospitals emergency room of Sheikh Yusuf Gowa $(\mathrm{n}=18)$

\begin{tabular}{ccc}
\hline \multirow{2}{*}{ Age } & $\mathbf{N}$ & $\mathbf{\%}$ \\
\cline { 2 - 3 } & $\mathbf{( F )}$ & $\mathbf{( \% )}$ \\
\hline 25-35 Years & 7 & 38.9 \\
36-45 Years & 8 & 44.4 \\
46-55 Years & 3 & 16.7 \\
\hline Total & $\mathbf{1 8}$ & $\mathbf{1 0 0 . 0}$
\end{tabular}

(Primary Data 2019)

Based on the characteristics of age, of a total of 18 respondents the average age of nurses is 36-45 years with the highest number of nurses 8 with the percentage of $44.4 \%$ and 3 nurses with age $46-55$ years with a percentage of $16.7 \%$. 
Tabel 3. Frequency Distribution of Respondents by Education Nurses in hospitals emergency room of Sheikh Yusuf Gowa $(n=18)$

\begin{tabular}{ccc}
\hline \multirow{2}{*}{ Education } & $\mathbf{N}$ & $\mathbf{\%}$ \\
\cline { 2 - 3 } & $\mathbf{( F )}$ & $\mathbf{( \% )}$ \\
\hline D3 & 6 & 33.3 \\
S1 & 1 & 5.6 \\
S1 + Nurses & 11 & 61.1 \\
\hline Total & $\mathbf{1 8}$ & $\mathbf{1 0 0 . 0}$ \\
\hline
\end{tabular}

(Primary Data 2019)

Based on the characteristics of Education, of the total 18 respondents on average most nurse education is $\mathrm{S} 1+$ nurses with the number of nurses 11 people with a percentage of $61.1 \%$ and 1 nurse with $\mathrm{S} 1$ in the percentage of $5.6 \%$.

Tabel 4. Respondents Frequency Distribution Based Training The penrnah Followed by a nurse at the hospital emergency room Shaykh Yusuf Gowa $(n=18)$

\begin{tabular}{ccc}
\hline Training The ever & $\mathbf{N}$ & $\mathbf{\%}$ \\
\cline { 2 - 3 } Followed & $\mathbf{F})$ & $\mathbf{( \% )}$ \\
\hline BTCLS & 17 & 94.4 \\
Do not follow & 1 & 5.6 \\
\hline Total & $\mathbf{1 8}$ & $\mathbf{1 0 0 . 0}$ \\
\hline
\end{tabular}

(Primary Data 2019)

Based on the characteristics of the training which have been followed by hospital emergency room nurse Sheikh Yusuf, of the total 18 respondents averaged nearly all been trained nurses BTCLS (Basic Training Cardiac Live Support) as much as 17 percentage of 94.4\% Nurses premises.

Tabel 5. Respondents Frequency Distribution Based on the validity of the Triage Nurse at Hospital emergency room Shaykh Yusuf Gowa $(\mathrm{n}=18)$

\begin{tabular}{ccc}
\hline validity Triage & $\mathbf{N}$ & $\mathbf{\%}$ \\
\cline { 2 - 3 } & $\mathbf{( F )}$ & $\mathbf{( \% )}$ \\
\hline Corresponding & 11 & 61.1 \\
It is not in & 7 & 38.9 \\
accordance with & & \\
\hline Total & $\mathbf{1 8}$ & $\mathbf{1 0 0 . 0}$ \\
\hline
\end{tabular}

(Primary Data 2019)

based on Characteristics validity Triage which is conducted by hospital emergency room nurse Sheikh Yusuf, of the total 18 respondents averaged nearly all nurses with appropriate triage dilahat da ri table 4.5 where as many as 11 nurses doing triage in accordance with the Standard Operational with a percentage of $61.1 \%$.

Tabel 6. Respondents Frequency Distribution Based on Response Time Nurses in hospitals emergency room of Sheikh Yusuf Gowa $(\mathrm{n}=18)$

\begin{tabular}{ccc}
\hline \multirow{2}{*}{ Response Time } & $\mathbf{N}$ & $\mathbf{\%}$ \\
\cline { 2 - 3 } & $\mathbf{( F )}$ & $\mathbf{( \% )}$ \\
\hline Very fast & 5 & 27.8 \\
fast & 8 & 44.4 \\
Slow & 5 & 27.7 \\
\hline Total & $\mathbf{1 8}$ & $\mathbf{1 0 0 . 0}$ \\
\hline
\end{tabular}




\section{Journal Of Nursing Practice}

http://thejnp.org

ISSN: 2614-3488 (print); 2614-3496 (online)

Vol.3 No.2. April 2020. Page.153-164

(Primary Data 2019)

based on Characteristics Response Time which is conducted by hospital emergency room nurse Sheikh Yusuf, can dilahat from table 4.6 of the total 18 respondents there were eight nurses who do Response Time quickly with a percentage of $44.4 \%$ and 5 nurse performs extremely fast response time and slow with a percentage of $27.8 \%$.

\section{Bivariate analysis}

In conducting the test Statistics about ValiditasTriage Relations and Response Time of nurses in providing services in hospital emergency rooms Sheikh Yusuf using Spearman rank correlation result crate in the following table:

Tabel 7. Validity relationship Triage and Response Time Nurses to provide services in hospital emergency room Shaykh Yusuf Gowa $(\mathrm{n}=18)$

\begin{tabular}{|c|c|c|c|c|c|c|c|c|}
\hline \multirow{3}{*}{$\begin{array}{c}\text { Response Time } \\
\text { Nurse }\end{array}$} & \multicolumn{4}{|c|}{ The validity of triage Nurse } & \multicolumn{2}{|c|}{ Total } & \multirow{3}{*}{$\begin{array}{c}\mathrm{P} \\
\text { value }\end{array}$} & \multirow{3}{*}{$\begin{array}{c}\text { Correlatio } \\
n \\
\text { coefficien } \\
t\end{array}$} \\
\hline & \multicolumn{2}{|c|}{$\begin{array}{l}\text { Correspondin } \\
\mathrm{g}\end{array}$} & \multicolumn{2}{|c|}{$\begin{array}{l}\text { It is not in } \\
\text { accordance } \\
\text { with }\end{array}$} & \multirow[b]{2}{*}{$\mathrm{n}$} & \multirow[b]{2}{*}{$\%$} & & \\
\hline & $\mathrm{n}$ & $\%$ & $\mathrm{n}$ & $\%$ & & & & \\
\hline Very fast & 3 & 16.7 & 2 & 11.1 & 5 & 27.8 & & \\
\hline fast & 5 & 27.8 & 3 & 16.7 & 8 & 44.4 & & \\
\hline slow & 3 & 16.7 & 2 & 11.1 & 5 & 27.8 & 0000 & 1,000 \\
\hline Total & 11 & 61.1 & 7 & 38.9 & 18 & 100.0 & & \\
\hline
\end{tabular}

(Primary Data 2019)

Based on the results of Rank Spearman test of the number of respondents 18 nurses where $\mathrm{p}$ value $>0.05$ then Ho is rejected and Ha received or it can be concluded that there is a significant relationship between the validity of triage and response time nurses in the health service in room ER Hospital Sheikh Yusuf can the results obtained from the above output correlation coefficient is 1.000 which shows a low correlation. This indicates a low correlation diakibatkn by the lack of the number of respondents.

\section{DISCUSSION}

In triage emergency care is a process of collecting information about the patient and begin the process of decision-making to categorize and prioritize the needs of the patient for treatment. Triage is done to ensure that patients are treated based on clinical urgency, ensure the right treatment and the right time, putting the patient with the most appropriate assessment, and determine the appropriate treatment area and to gather information that could be useful for the development of triage in the ER (Ganley, 2011).

The results showed that the majority of respondents are in the age of over 36 years is by 8 respondents $(44.4 \%)$. According Notoatmojo (2010) influence the age of perception and mindset of someone, increasing age will be growing anyway comprehension and thought patterns so that the knowledge gained is getting better.

Maturity individuals can be seen directly objectively age period, so that the various processes of experience, knowledge, skills, independence associated with advancing age of the individual. A much older age, will tend to have more experience in dealing with problems. 


\section{Journal Of Nursing Practice}

http://thejnp.org

ISSN: 2614-3488 (print); 2614-3496 (online)

Vol.3 No.2. April 2020. Page.153-164

In early adulthood trained health worker can perform triage action for adulthood is a time when a person reaches the peak of his intellectual abilities, Critical thinking skills has increased regularly during adulthood (Potter \& Perry, 2009)

The results showed that the respondents' gender men and women show the same number that is 9 with a percentage of $50 \%$. Where the nurses working still great demand by women than men because nursing is still identified with a suitable job and in accordance with the nature of women is more patient, gentle, and caring. According to the research results Affleck (2013) found that the majority of respondents are male. This shows that health workers needed IGD more energy to handle some cases seriously enough.

The results showed that most respondent bachelor education+ nurses as many as 11 respondents with the percentage $(61.1 \%)$. The higher one's education, the more freely they also receive information and have a lot of knowledge of the latest to.

This is in line with research conducted by Fitriyanti (2016) who said that the higher education can improve the skills of nurses, also higher one's education, the more critical, logical and is stematics way of thinking, and the higher the quality of work (Fitrianty \& Suryati 2016). While the study was conducted Maatilu (2014) showed that no significant relationship between nurse education with a response time nurse in the handling of emergency patients. In assessing the skills of someone who is in this case the response time nurse, could have been influenced by the existence of other factors, this situation depends on the motivation of nurses practicing occupational skills gained from her education.

From the results, almost all the nurses that 17 people were in hospital emergency room ER Sheikh Yusuf Gowa has followed the basic training that is BTCLS (Basic Training Cardiac Live Support). With their participation in a training nurse has been able to conduct a triage activity or response time to the right, because the nurses had had enough skill.

From the results of the study, indicating that as many as 11 nurses (61.1) do Triage appropriately or appropriate and as many as seven nurses (38.9\%) were not appropriate in Triage with improper conduct or inappropriate. Where the main purpose in doing triage is to minimize the occurrence of errors and increasing patient injured in the rescue.

Results of research by Gustia \& Manurung (2018) about the relationship of the accuracy of ratings triage with a success rate of treating patients with head injuries in the ER RSU HKBP Balige Toba Samosir regency which is a type C hospital in Sumatra showed the success of ratings triage by 14 people $(82.36 \%)$ and in getting the relationship between the accuracy of triage assessment with a success rate of treating patients with head injury. However, different research results Evie, et al. (2016) obtained type C hospital ER unfortunate there are 27 people $(77.1 \%)$ of the 35 respondents were not appropriate triage implementation due to factors related to the study namely emergency training by nurses. Mutiarasari (2019) states that health services according to the procedure is one of the indicators assessing the precise implementation of the service of a hospital, which had a significant impact for patients and for personnel and hospital if implemented properly, but if not done in accordance with the standard procedure of the hospital then it will affect not good for patients, staff and the hospital itself.

From the research results be obtained from a total of 18 respondents mostly have a rapid response that is 8 times by the nurses (44.4\%). In conducting the response time (response time) service is a combination of the response time when the patient arrives at the front door of the hospital until the patient get treatment early or the response of the 
emergency department personnel at the time used to complete the patient is given relief (Sutriningsih, 2014). Research conducted by Tumbuan (2015) results nurse response time in handling emergency cases in the ER RSU also GMIM Kolooran Amurang type C hospital most (57.1\%) slow. This is not in accordance with the Decree of the Minister of Health (2009) which states that emergency patients should be treated in $<5$ minutes.

Observations obtained while doing research in getting to a very fast handler nurses handle are the main complaints of patients with loss of consciousness that directly dirakhakan in this case the action space suit your accuracy triage performed by nurses. And for a quick handler according to the results of observations made when the patient is somewhat less in the room nurses were able to perform with quick response time.

Furthermore, the unequal distribution of the gravity that comes mostly yellow and green triage category according to Mahyawati (2015) states that there is uneven distribution of the level of severity, the presence of officers in the triage, the availability of facilities and how to pay for the patient are factors which cause the response time (Response time) in excess of the standard that has been set. Further research conducted by Mahyawati (2015) about the relationship with the patient emergency response time nurse in the ER RS PKU Muhammadiyah Yogyakarta concluded that there is a relationship between the emergency medical service response time which the higher of the degree of severity of patients it will response time fastly.

The delay in response time nurses in taking action would be bad for the patient and hospital services and the number of complaints that will be felt by the patient's family and many other factors that are capable menghanbat in the handler but the most important of which is the implementation of the triage, the willingness of infrastructure hospitals and services other supporting health.

Analysis of the relationship anatara validity of triage and response time of the results of hypothesis testing conducted using Spearman Rank Correlation test menunjukka $\mathrm{p}=$ $0.000<\alpha=0.05$. Thus it can be concluded that there is a significant relationship between the accuracy of the response time of triage by nurses in hospitals ER Sheikh Yusuf Gowa.

The results of this study are supported by Mahyawati (2015) about the relationship with the patient emergency response time nurse in the ER RS PKU Muhammadiyah Yogyakarta concluded that there is a relationship between emergency response time in which the higher the level of severity of patients the response time will be faster. This study shows that of the total respondents $18(100 \%)$ there were $11(61.1 \%)$ who did triage exactly have a fast response time of 8 persons $(44.4 \%)$ while the slow response time of as much as 3 people $(16.7 \%)$ ). This occurs because of the other factors that cause slow response time such as the sex and age characteristics.

The results of observations researchers in space IGD other factors in getting the lack of health workers, especially nurses in the room IGD where only 25 nurses outside the head tendency and KTU Unit in the ER Hospital Sheikh Yusuf Gowa Sementra patient visits each month nearly 1000 people and daily visits Average -rata sebnyak 40-50 and uneven on each Sift performed by nurses so that nurses sometimes overwhelmed in dealing with patients.

In accordance with Dadashzadeh, et al. (2014) explains that one of the factors related to the implementation of the triage is the ratio of the number of nurses and patients. No imbalance between the availability of human resources with a number of patient visits that many will potentially delay the treatment of patients that would be fatal even deadly to patients with emergency conditions. 
Another factor is the length of time needed when doing initial assessment at triage room most respondents do not pay attention to the time of study, then the lack of infrastructure such as beds and wheelchairs so delayed in the given action and therefore a lengthening of the time response time.

The results of the research crosstab for respondents who perform triage with not exactly have a slow response time as many as five people (27.8\%) This happens because of declining ratings triage scale can extend the handling time which should be received by the patients according to their clinical condition and then will decrease the risk of patient safety and quality of health services (Khairina, 2018).

Based on observations in space IGD researchers have had a groove triage and indoor spaces such as room triage, resuscitation, surgery observation, observation of the child, the isolation room, living room and the surgical action and the apparent absence of color strips on the floor of the ER triage her. Most respondents have been doing triage in conformity with 5 points seen in triage accuracy of the observation sheet 1 . Patients come accepted attendant / paramedics, 2. In the room triage is done anamnesis, 3. Determination of the degree of severity, priority services 4 . Distribution, 5 . Handle the patient with priority.

Implementation of the triage greatly affect the response time, if the triage is not done properly then it will slow down the response time (response time) that will be acceptable to the patient so that it will increase the risk of organ damage or disability, and even to the death of the patient. In addition it will also affect the quality of health care will increase the hospital and the patient care costs.

In nurses theory models which in the view of nursing, nursing models Roy, known for Roy's adaptation model which looked at every human being must have the potential to be able to adapt to stimuli both internal and external stimuli and adaptability can be seen from various age levels. Behavioral adaptation is the functioning of the stimulus and the degree of adaptation that may affect the focal stimulus, stimulus contextual and residual stimuli.

In nursing care, according to Roy in 1984 as a recipient of nursing care that individuals, families, communities perceived as "Holistic adaptation system" in all its aspects is an integral manner. In the adaptation model of nursing, man is described as an open system, and adaptive. As the human adaptive system can be described in terms of the characteristics of the system. Humans are seen as interconnected unity between functional units as a whole. Human control processes as a system. Adaptation is a coping mechanism, consisting of regulator and cognator, both described as action in relation to the four effector way of adaptation is the function of physiological, self-concept, role function and interdependence

Healthy concept according to Roy where he defines health is a state and a process to be fully human and fully integrated overall (Roy and Andrews, 1991 in Nursing Theory: 261). Integrity of the individual can be demonstrated by the ability to defend themselves, grow, reproduce and power. Nursing is based on Roy's model aims to improve the health of individuals by improving their adaptive response. Definition of health is more than the absence of illness but an emphasis on healthy and prosperous.

This is in line with the theoretical model of nursing Jean Watson, who said that a man believed to be the person as a whole, as a fully functional integrated self. Jean Watson define healthy as intact condition and in harmony between body, mind, and soul, is related to the level of concordance between self-perceived and self-manifested. From some healthy concept can be expressed pain over some matters of principle, such as: Healthy 


\section{Journal Of Nursing Practice}

http://thejnp.org

ISSN: 2614-3488 (print); 2614-3496 (online)

Vol.3 No.2. April 2020. Page.153-164

describes a person's integrity conditions that are multidimensional, which can fluctuate depending on the interrelations between factors that influence. Healthy condition can be achieved, because of the person's ability to adapt to both internal and external environment. Healthy can not be stated as a condition that stops at a certain point.

Jean Watson in comprehend nurses concept as usual we know it with knowledge human being theory and nurses of the human. The measurement of Watson theory according to theory human being element. In Jean Watson opinions believing that human being have four affiliate necessity which mutually connected like biophysics necessity (for life) including food necessity and fluid, eliminate necessity and ventilation necessity, psychological (fungtional needs) which pervade activity and resting, sexuality, psychosocial (integration needs) which pervade achievement necessity, organitation .and intra and interpersonal necessity (necessity for developing) viz self-actualization necessity.

Based on the four requirements, Jean Waston understand that human beings are perfect beings who have a variety of diverse differences, so in an effort to achieve health, people should be in the prosperous state of physical, mental and spiritual as peace is harmony between mind, body and soul so as to to that state nursing should play a role and improve health status, prevent disease, treat a variety of diseases and health healing and the focus on health promotion and disease prevention.

Jean Watson's theory has been published in nursing is a "human science and human care". Watson believes that the main focus in nursing is at carative factor stems from the humanistic perspective combined with scientific poengetahuan basis. Therefore, nurses need to develop filososfi humanistic and value system as well as a strong arts. Humanistic philosophy and value system is the member firm foundation for nursing, while the base of art can help nurses develop their vision and values of the world and critical thinking skills. The development of critical thinking skills required in nursing care, but the focus is more on improving health, not treatment of disease.

"Theory of Human Caring"(Watson), reinforce the kinds of relationships and transactions required between the giver and receiver of care to improve and protect the patient as a human being that affect the ability of the patient to recover.

Watson argued that caring is the essence of nursing. In this case caring is the embodiment of all the factors used nurses in providing health services to the client. Then caring also emphasize individual dignity, meaning that in practice nursing, nurses always always appreciate clients to receive excess or lack of clients. Watson also noted that the response of each individual to a health problem is unique, meaning that in the practice of nursing, a nurse must be able to understand each different response from the client to the agony and provide health services right in each different response which is being, or will happen, Other than that, caring only be shown in the interpersonal relationship is the relationship between the nurse with the client, which shows the caring nurse through attention, intervention to maintain the client's health and positive energy given to the client. Watson also believes that caring includes a commitment to provide nursing care based on science. In practice, the nurse is challenged to not hesitate in using its knowledge in nursing practice.

\section{CONCLUSION}

The validity of conclusions about the relationship Triage and Response Time memebrikan nurses in health services in the Emergency Hospital Intsalasi Sheikh Yusuf Gowa: 
1. Triage implementation in hospitals emergency room of Sheikh Yusuf Gowa from the observations made during the two days showed that the nurses have been able to do a proper dangan Triage.

2. Response Time in providing services in hospital emergency rooms Sheikh Yusuf Gowa can already fast handling dikategorian

3. Rank test of hasi Spearman Rank with a P value $<0.05$ then a significant relationship between validity and Response Time Triage Nurse in the ER Sheikh Yusuf Hospital Gowa 


\section{Journal Of Nursing Practice}

http://thejnp.org

ISSN: 2614-3488 (print); 2614-3496 (online)

Vol.3 No.2. April 2020. Page.153-164

\section{REFERENCES}

American College of Emergency Physicians. (2008). Emergency department crowding: high-impact solutions. ACEP task force report on boarding.

Arikunto, S. (2010). Research procedure a practical approach. Jakarta: PT Rineka Reserved.

Affleck, A., Parks, P., Drummond, A., Rowe, B. H., \& Ovens, H. J. (2013). Emergency department overcrowding and access block. Canadian Journal of Emergency Medicine, 15(6), 359-370. https://doi.org/10.1017/s1481803500002451

Dadashzadeh, A., Abdolahzadeh, F., Rahmani, A., \& Ghojazadeh, M. (2014). Factors affecting triage decision-making from the viewpoints of emergency department staff in Tabriz hospitals.

Fitriyanti, L., \& Suryati, S. (2016). Hubungan Karakteristik Perawat dengan Motivasi Kerja dalam Pelaksanaan Terapi Aktivitas Kelompok di Rumah Sakit Khusus Daerah Duren Sawit Jakarta Timur. Jurnal Ilmiah Kesehatan MH Thamrin, 8(1).

Ganley, L., \& Gloster, A. S. (2011). An overview of triage in the emergency department. Nursing Standard (through 2013), 26(12), 49.

Gravel, J., Manzano, S., \& Arsenault, M. (2009). Validity of the Canadian Paediatric Triage and Acuity Scale in a tertiary care hospital. Canadian Journal of Emergency Medicine, 11(1), 23-28. https://doi.org/10.1017/S1481803500010885

Gustia, M., \& Manurung, M. (2018). Hubungan ketepatan penilaian triase dengan tingkat keberhasialan penanganan pasien cidera kepala di igd rsu hkbp balige kabupaten toba samosir. Jumantik (Jurnal Ilmiah Penelitian Kesehatan), 3(2), 98-114. http://dx.doi.org/10.30829/jumantik.v3i2.1985

Hammond, B. B., \& Zimmermann, P. G. (Eds.). (2012). Sheehy's Manual of Emergency Care-E-Book. Elsevier Health Sciences.

Khairina, I., Malini, H., \& Huriani, E. (2018). Faktor-Faktor yang Berhubungan dengan Pengambilan Keputusan Perawat Dalam Ketepatan Triase Di Kota Padang. Indonesian Journal for Health Sciences, 2(1), 1-6.

Mahyawati, M., \& Widaryati, W. (2015). Hubungan Kegawadaruratan Pasien dengan Waktu Tanggap Perawat di IGD RS PKU Muhammadiyah Yogyakarta (Doctoral dissertation, STIKES'Aisyiyah Yogyakarta).

Maatilu, V., Mulyadi, N., \& Malara, R. (2014). Faktor-Faktor yang Berhubungan dengan Response Time Perawat pada Penanganan Pasien Gawat Darurat di IGD RSUP Prof. Dr. RD Kandou Manado. Jurnal Keperawatan, 2(2).

Mahrur, A. (2015). FAKTOR-FAKTOR YANG MEMPENGARUHI LAMANYA WAKTU TANGGAP DALAM PELAYANAN GAWAT DARURAT DI INSTALASI GAWAT DARURAT RSUD Dr. SOEDIRMAN KEBUMEN (Doctoral dissertation, STIKES MUHAMMADIYAH GOMBONG).

Ministry of Health. (2018). Peraturan Menteri Kesehatan Republik Indonesia Nomor 47 Tahun 2018 Tentang Pelayanan Kegawatdaruratan. Jakarta.

Mudatsir, S., Sangkala, M. S., \& Setyawati, A. (2017). Related Factors of Response Time in Handling Head Injury in Emergency Unit of Prof. Dr. HM Anwar Makkatutu Bantaeng General Hospital. Indonesian Contemporary Nursing Journal, 2(1), 1-12. http://dx.doi.org/10.20956/icon.v2i1.3579

Mukhtar, H. M. E., Fadlallah, F. A. (2018). Nurse's Knowledge Regarding Triage System At Emergency Departments In Public Hospital At Khartoum State. Proceedings of Researchfora 33rd International Conference, Jeddah, Saudi Arabia. 15-17. 
Musliha. 2010. Keperawatan Gawat Darurat. Yogyakarta: Nuha Medika.

Mutiarasari, D., ., M., \& Puspasari, I. (2019). Response Times and Patient Satisfaction in Emergency Room at Anutapura General Hospital, City of Palu. Journal of Current Medical Research and Opinion, 2(05), 152-157.

https://doi.org/10.15520/jcmro.v2i05.165

Notoatmodjo, S. (2010). Metodologi Penelitian Kesehatan. Jakarta: Rineka Cipta.

Potter, P. A., Perry, A. G. E., Hall, A. E., \& Stockert, P. A. (2009). Fundamentals of nursing. Elsevier Mosby.

Sutriningsih, A. (2014). Faktor yang berperan dalam pembentukan persepsi tingkat kegawatan perawat dan keluarga pasien pada kasus kecelakaan lalu lintas (KLL) di IGD RSUD dr. Saiful Anwar Malang (Doctoral dissertation, Universitas Brawijaya).

Tumbuan, A. N., Kumaat, L., \& Malara, R. (2015). Hubungan Response Time Perawat Dengan Tingkat Kecemasan Pasien Kategori Triase Kuning Di IGD RSU GMIM Kalooran Amurang. JURNAL KEPERAWATAN, 3(2). 